\title{
Study of an Uplift of Sargodha High by Stratigraphical and Structural Interpretation of an East-West Seismic Profile in Central Indus Basin, Pakistan
}

\author{
Shazia Asim¹, Shahid Nadeem Qureshi², Nasir Khan ${ }^{1}$ \\ ${ }^{1}$ China University of Geosciences (CUG), Wuhan, China \\ ${ }^{2}$ COMSATS Institute of Information Technology (CIIT), Islamabad, Pakistan \\ Email: shazia.asim1@gmail.com, snq05@hotmail.com, geonasirkhan@hotmail.com
}

Received 11 July 2014; revised 1 August 2014; accepted 16 August 2014

Copyright (C) 2014 by authors and Scientific Research Publishing Inc.

This work is licensed under the Creative Commons Attribution International License (CC BY).

http://creativecommons.org/licenses/by/4.0/

(c) (i) 0 pen Access

\section{Abstract}

Research Area comprises of Punjab Monocline, Sulaiman Foredeep and Eastern Part of Sulaiman Fold Belt (from east to west) in Central Indus Basin, Pakistan. Sargodha High is located in northeast of a Seismic Profile AB. Time and Depth models show the subsurface crustal variations near Sargodha High, which separates Upper Indus Basin from Central Indus Basin. The deposition of Pre-Cambrian sediments is uniform in area and Paleozoic sediments (Permian \& Cambrian) are thinning in west. Mesozoic sediments (Cretaceous, Jurassic \& Triassic) and younger sediments (Paleocene) are not deposited in this part suggesting an uplift of Sargodha High during Paleozoic time. An uneven distribution of Paleozoic rocks shows some thickness in east but erosion, thinning and almost truncation in west indicate their depocenter in east. This also represents a time of uplift of Sargodha High that shifts depocenter westward. Seismic data show a thick Mesozoic deposition in west, which onlaps on the Permo-Triassic unconformity suggesting an area of non-deposition. The gradual uplift of Sargodha high continues, which tilts the Mesozoic strata forming wedge shape geometry.

\section{Keywords}

Uplift, Unconformities, Structural Truncations, Depo-Center, Basement

\section{Introduction}

Research area lies close to Sargodha High, which separates Upper Indus Basin from Lower Indus Basin, Pakis-

How to cite this paper: Asim, S., Qureshi, S.N. and Khan, N. (2014) Study of an Uplift of Sargodha High by Stratigraphical and Structural Interpretation of an East-West Seismic Profile in Central Indus Basin, Pakistan. International Journal of Geosciences, 5, 1027-1036. http://dx.doi.org/10.4236/ijg.2014.59088 
tan (Figure 1). This area is scarcely investigated in past as this is a first research attempt in the area of such type, in which seismic data are incorporated. Previously, in some cross sections Pre-Cambrian, Paleozoic (Permian, Cambrian) and Mesozoic (Cetaceous, Jurassic, Triassic) were not discussed separately. Some cross-sections were made only in Time domain. Mostly the geological cross-sections were made. The seismic data collected were studied for the search of hydrocarbons (as the specific zones of interest were marked and only the structures and formations within this zone were studied). In this research, seismic data are incorporated to get time and depth models of an area. This study is beneficial in various relevant fields such as Petroleum geology, Sedimentology, Seismic Stratigraphy, Structural geology, Tectonics, Geodynamics and Basin analysis for researchers and industries.

\section{Previous Work Done}

A generalized view is obtained by the efforts of various authors.

[1] explained the tectonic configuration of the Sargodha Ridge as an outer "swell" due to loading of Indian

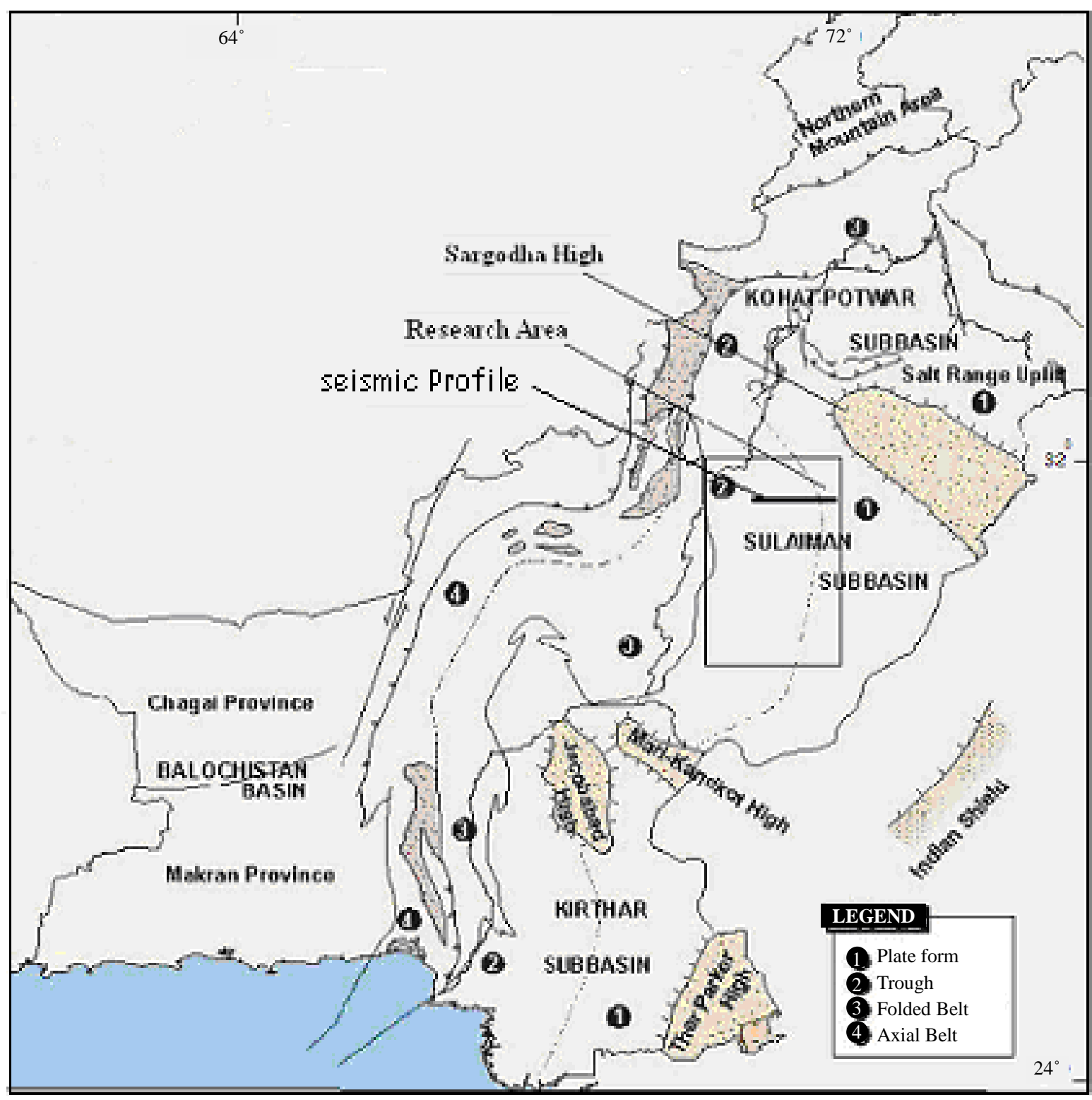

Figure 1. Geological map showing the location of research area and a seismic line (www.gsp.com). 
Shield by the Himalayan thrusts. This suggests that Sargodha Ridge is seismically active and belongs to Punjab seismic zone of [2] that includes the Hissar Ridge and extends to Dehli, India ([3]-[5]).

\section{Objectives}

To study an uplift of Sargodha High and changes in basin depocenters with the passage of time associated with uplift.

\section{Geology and Tectonics of Central Indus Basin}

Research area lies in the Central Indus Basin of Pakistan. Central Indus Basin may be divided into following broad tectonic divisions from east to west [6].

1) Punjab Platform; 2) Sulaiman Depression; 3) Sulaiman Fold Belt (Figure 1).

The basin is separated from Upper Indus Basin by the Sargodha High \& Pezu uplift in north. It is bounded by Indian shield in the east, marginal zone of Indian Plate in the west, and Sukkur rift in the south. It is the Sargodha High in fact which is considered to be a divide between Upper Indus Basin and Lower Indus Basin [3]. Another major feature of basement topography, as seen on the gravity data, is the Khairpur-Jacobabad High \& its associated structures which grew through Jurassic \& Cretaceous/Paleocene ages \& divide the Lower Indus Basin further into two basins namely Southern and Central Indus Basin. The Southern \& Central Indus Basins are separated by Jacobabad \& Mari-Kandhkot highs together termed as the Sukkur Rift [7].

The oldest rocks exposed in this basin are of Triassic age (Wulgai Formation) while the oldest rocks penetrated through drilling are of Precambrian Salt Range Formation. The depth to the basement is about 15,000 meters in the Trough areas. Precambrian shield rocks are evident along the rim of the Indian Plate [6].

\section{Punjab Platform}

[3] describes this part as the eastern segment of Central Indus Basin where no surface outcrops of sedimentary rocks are present. Tectonically it is a broad monocline dipping gently towards the Sulaiman Depression. Punjab Platform is tectonically the least affected area because of its greater distance from collision zone. A number of wells have been drilled on this platform. The stratigraphic sequence established on the basis of these wells revealed some of the most significant stratigraphic pinch outs in Pakistan.

\section{Sulaiman Foredeep}

The Sulaiman Foredeep is also called Sulaiman Depression. This depression is longitudinally oriented area of subsidence; it becomes arcuate and takes up a transverse orientation along its southern rim. Like many other features, this depression was also formed as a result of the collision between two plates. The seismic evidence shows some buried anticlines (e.g. Ramak) which may have been formed due to the flow of Eocene shales [6].

\section{Sulaiman Fold Belt}

This is a major tectonic feature in the proximity of collision zone \& therefore contains a large number of disturbed anticlinal features [6]. There are some large anticlines within Kirthar and Sulaiman belts and especially along the eastern margins that are clearly detachments. The northward-striking east sulaiman structural play domain has narrow, straight anticlines as long as tens of kilometers with limbs that are broken locally by steeply dipping faults with reverse dip separation. These structures are interpreted as flower structures that are products of large-scale distributive wrench faulting having a prospective reservoir like Ranikot Formation (Paleocene), Pab Formation, Sember Formation and Lower Goru Formation of Cretaceous age [8]. Three basement faults separate these basement blocks from each other and from the central part of the Indo-Pakistan Plate. The Khuzdar Block and the Sulaiman Block are separated by the Kirthar Basement Fault, the Sulaiman Block and the Hazara Block by the Sulaiman Basement Fault and the Hazara Block and main body of the Indo-Pakistan Plate to the east are separated by the Jhelum Basement Fault [9].

\section{Stratigraphy of Area}

The research area lies in Central Indus Basin of Pakistan (Figure 2). Stratigraphic correlation for Paleozoic and 


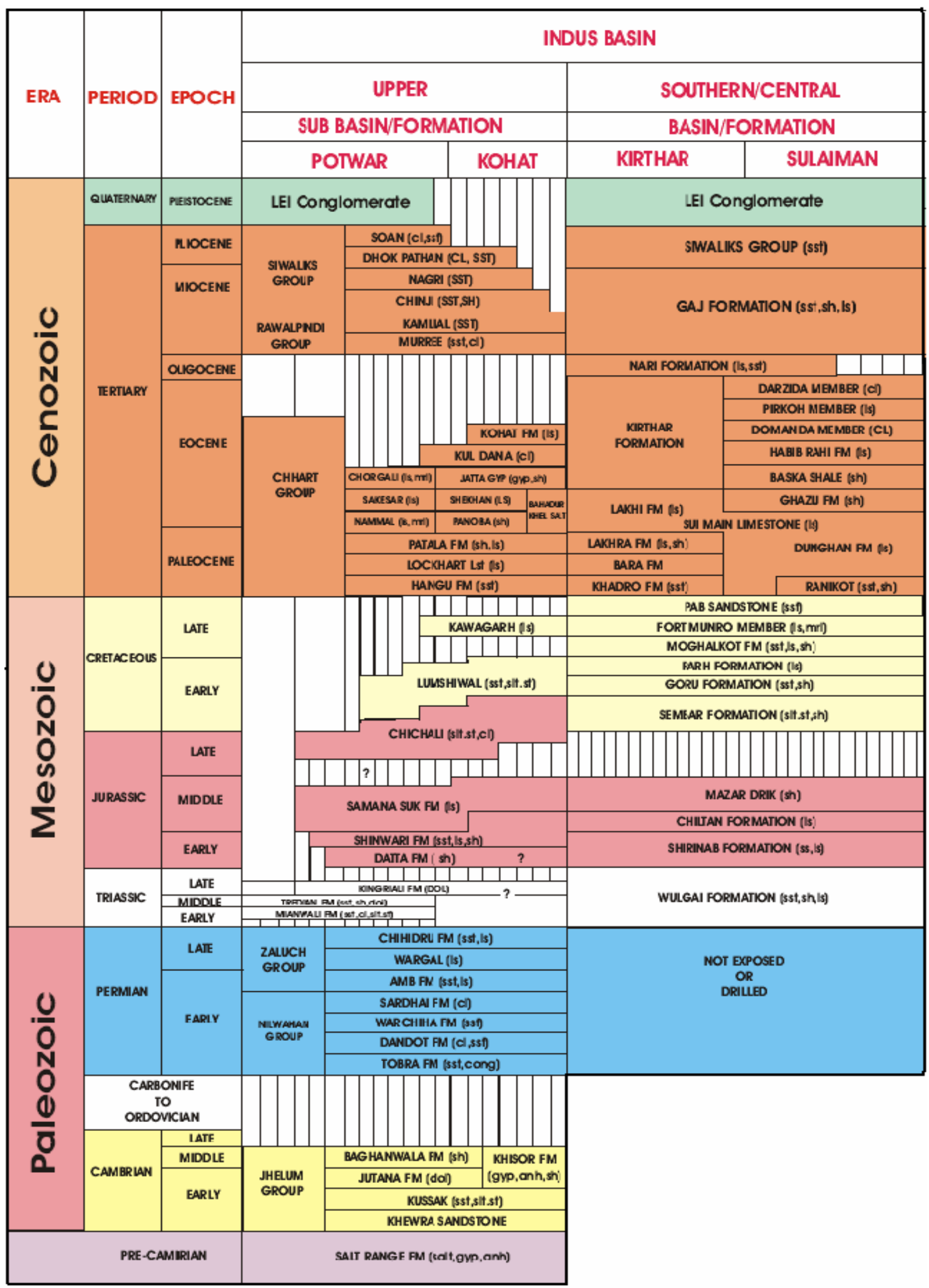

Figure 2. Stratigraphy of pakistan (Kadri, 1995). 
Pre-Cambrian rocks is performed from the wells in east (Darbula-01, Sarai Sidhu-01 and Bahawalpur East-01) drilled in Platform area. The wells in western part of the area are drilled in Mesozoic rocks. They also indicate the presence of Late Oligocene-Early Miocene sediments. The subsurface extend of these sediments is further studied in Time and Depth Models generated in this study.

\section{Methodology}

Research is based on the Structural and Stratigraphical interpretation of a seismic Profile, which lies in north eastern part of research area close to Sargodha High (Figure 1). Stratigraphic correlation of seismic data is done with the help of well data, Formations' top, Synthetics and general stratigraphy of area. Wells Kamiab-01, Saro-01 and Bhudhuana-01 are used for reflector correlation of formations from Jurassic to younger (Figure 3). Also wells Saro-01 (south) and Darbula-01 (North) are used for reflector correlation of Pre-Cambrian and Paleozoic formations (Figure 4). With the help of above mentioned wells the reflectors are marked on a seismic section (Figure 5). The Time and Depth models are generated with the help of Average velocities (Figure 6) to study the subsurface crustal variations in detail.

\section{Interpretation}

Features associated with an uplift of Sargodha High are present and marked on the seismic section (Figure 5). Permo-Triassic unconformity is marked in Punjab Platform area. On the other hand western end shows the presence of Pre-Cambrian sediments in the Sulaiman Foredeep area also. Time Model in Figure 7 shows sediments along with basement are uplifted in east near Sargodha High in Punjab Platform. Depth Model shows towards Punjab Monocline (east), sedimentary cover is less than $2 \mathrm{~km}$ and it is more than $9 \mathrm{~km}$ thick in a Sulaiman

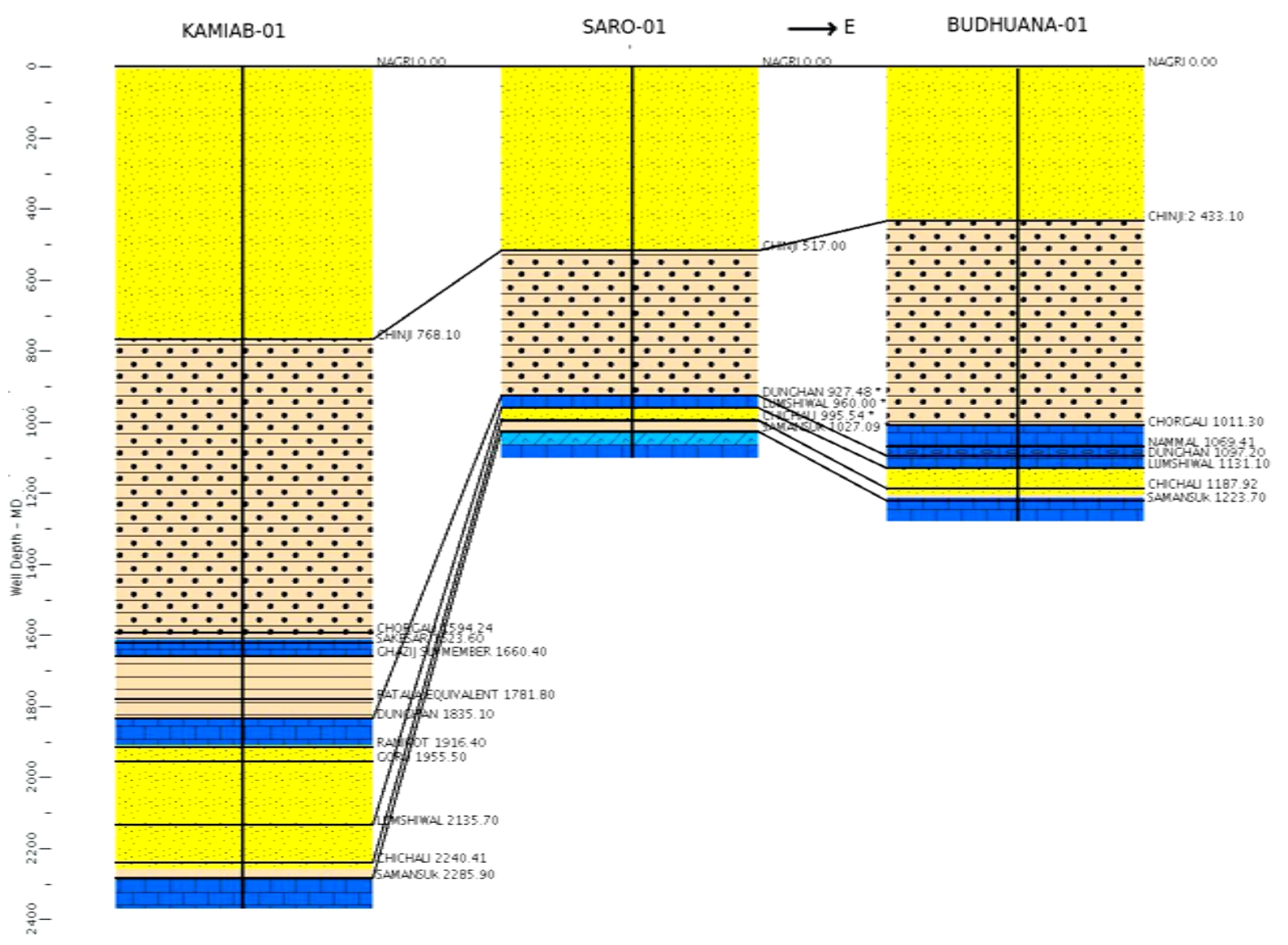

Figure 3. Wells Kamiab-01, Saro-01 and Darbula-01 are used for reflector correlation of formations from Jurassic to younger. 


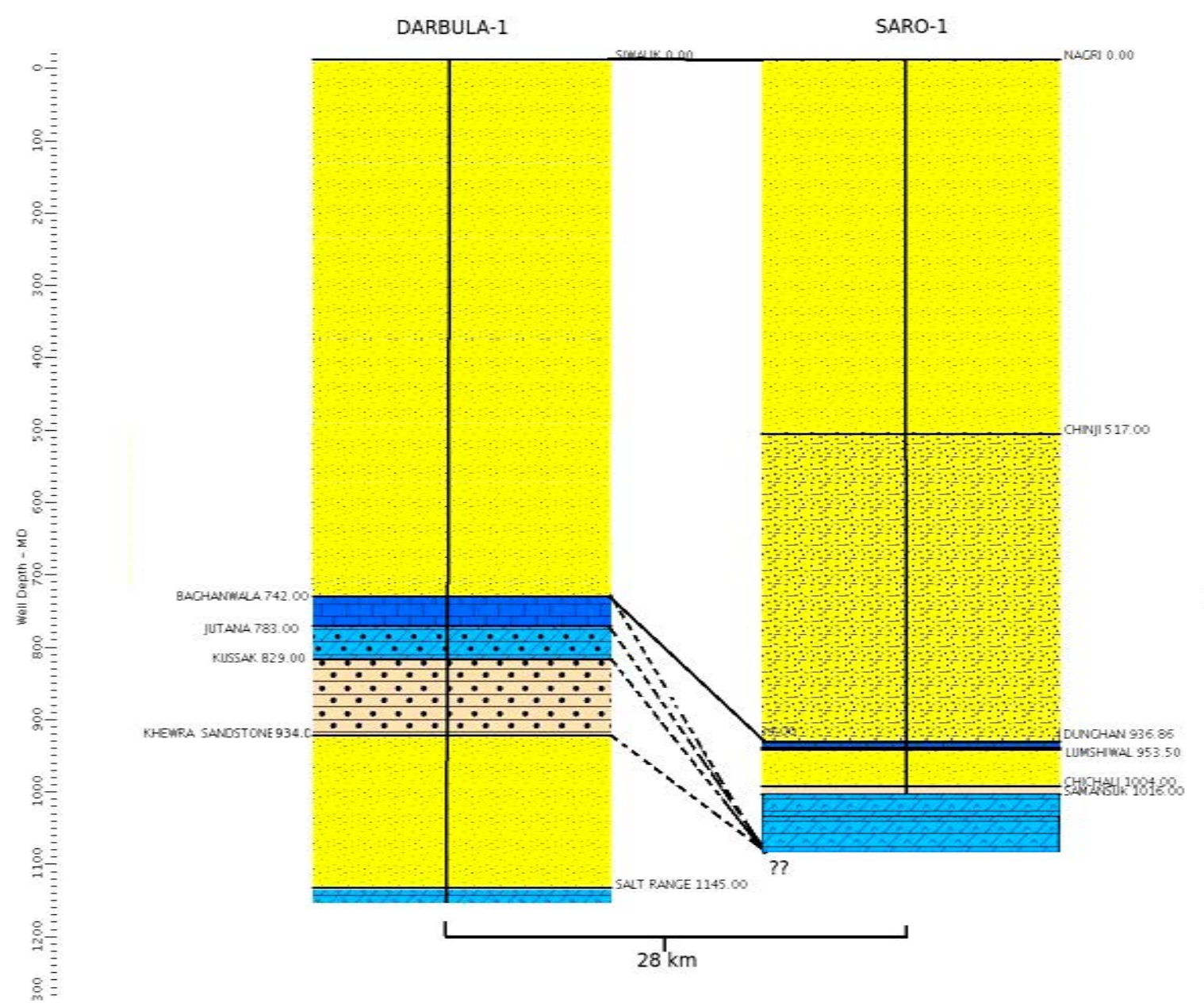

Figure 4. Wells Saro-01 (south) and Darbula-01 (North) are used for reflector correlation of Pre-Cambrian and Paleozoic formations.

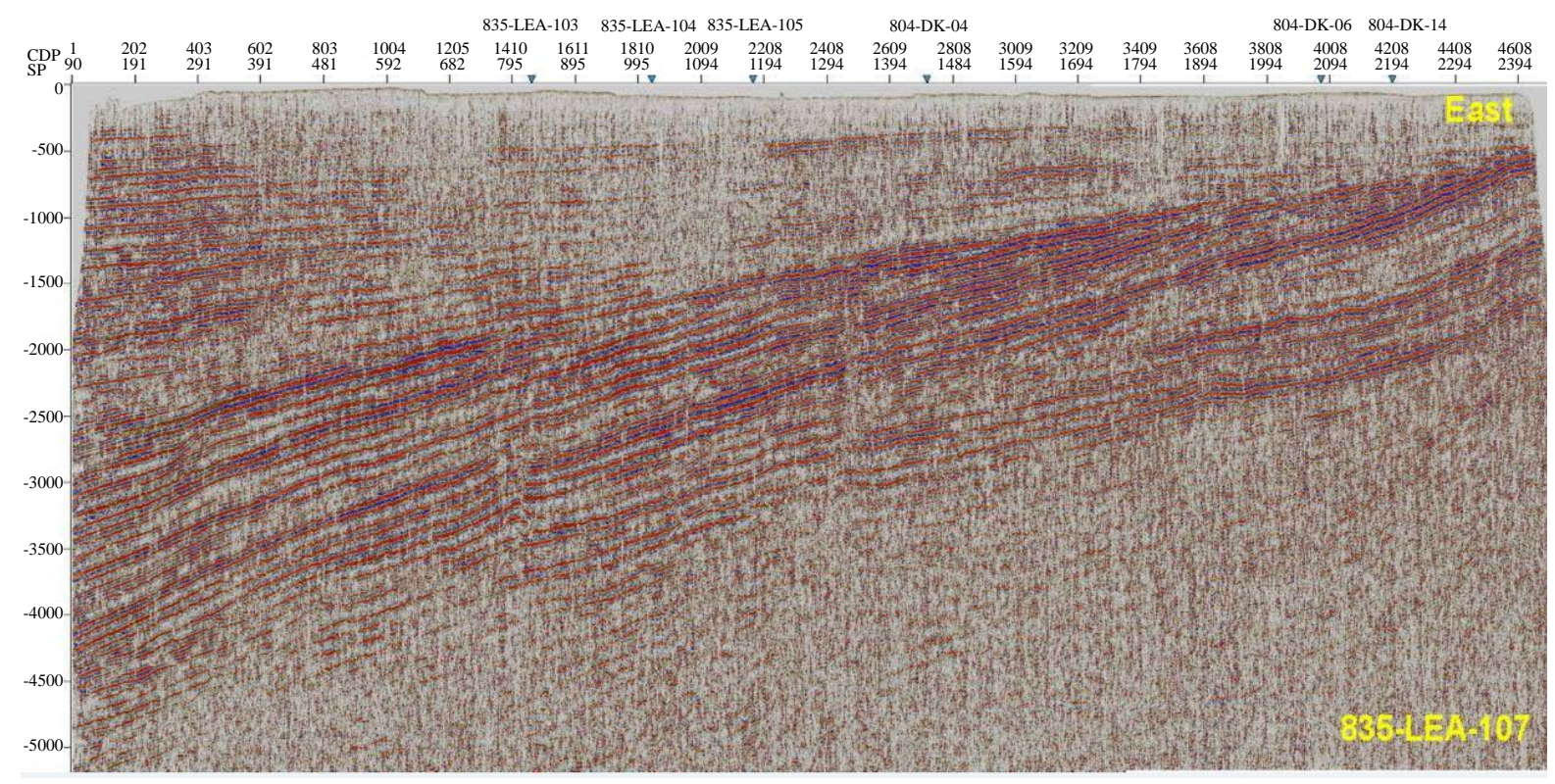

Figure 5. Seismic section of 835-LEA-107. 


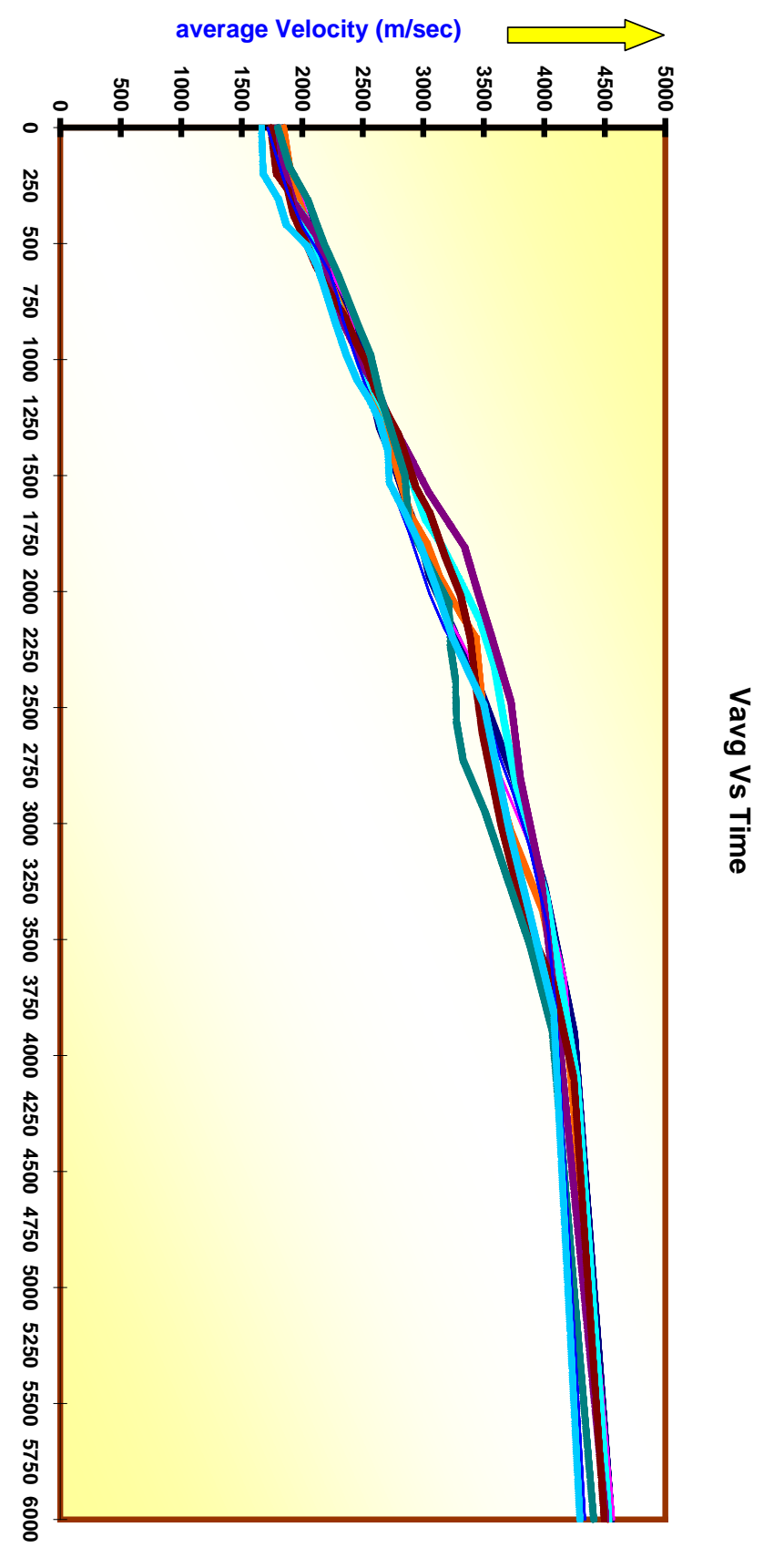

Figure 6. Average velocities used in depth computations.

Foredeep area (Figure 8). Sargodha High lies close to north east of seismic Profile. The features shown in Figure 9 and Figure 10 suggest an uplift of Sargodha High during Paleozoic age. Permo-Triassic unconformity shows an area of non deposition for Mesozoic and Paleocene sediments. It is confirmed by Triassic onlaps on Permian strata (Figure 9). Another major episode of uplift of sediments is suggested after Paleocene age associated with the collisional factor of Indian Plate.

A continuous deposition of Pre-cambrian is suggested in area. Afterwards Cambrian formations are deposited with their depocenter in east and westward thinning of these sediments in section marks the western edge of basin. During Permian the deposition was not uniform and at that time the uplift of Sargodha High must have began. Thinning and onlapping of Cretaceous \& Jurassic sediments in east explains an event of uplift of Sargodha High shifted the depocenter for Mesozoic in west (Figure 10). 


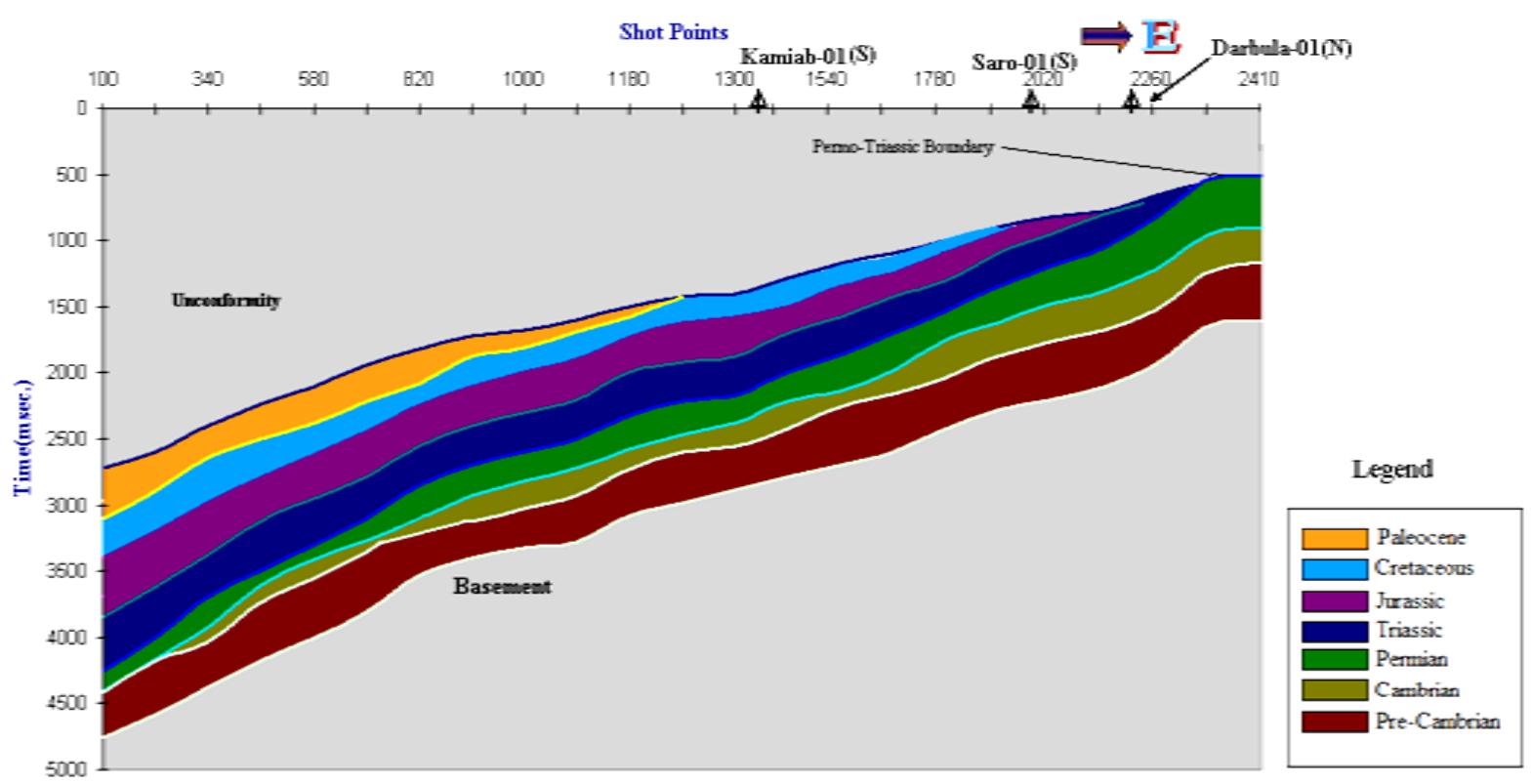

Figure 7. Time model of seismic profile.

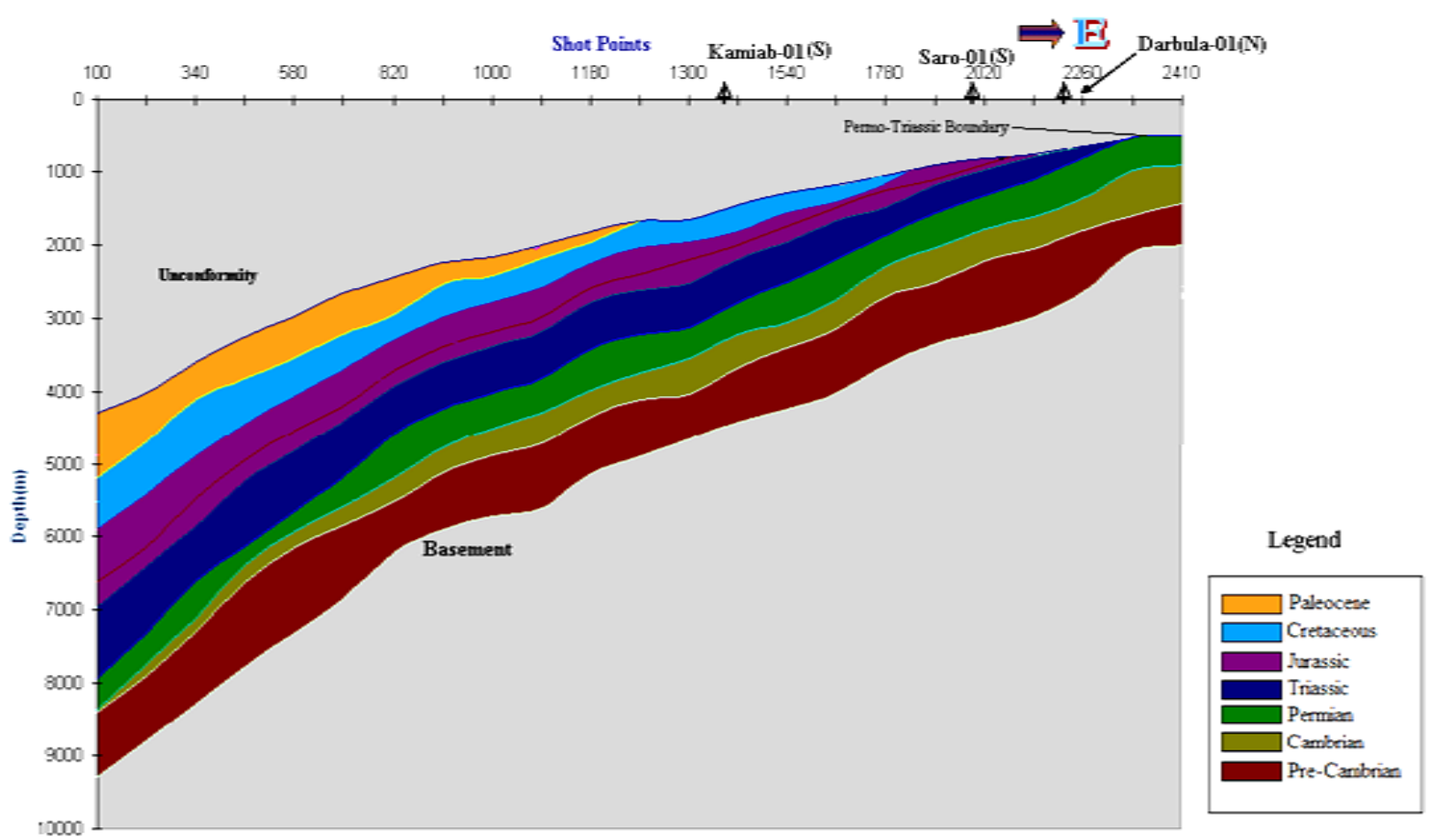

Figure 8. Depth model of seismic profile.

A set of normal faults appears due to presence of a Salt dome (Figure 11). Normal faults of local extent are generally associated with other structures whose geometry requires extension of crustal layers, e.g. domes etc. structural domes cut by a system of normal faults commonly result from the intrusion of bodies of salt or magma. The faults radiate from the center of the dome and may include a single major fault, one or two grabens or a Y shaped set of grabens. At depth the faults terminate at or near the margin of the dome [10].

Cambrian and Pre-Cambrian sediments have a carbonate buildup (Figure 12). Carbonate buildups, including reefs and banks, form important and prolific hydrocarbon reservoirs in many operating areas of the world, particularly in the US, Canada, North Africa, Mexico, Southeastern Asia and the Middle East. 


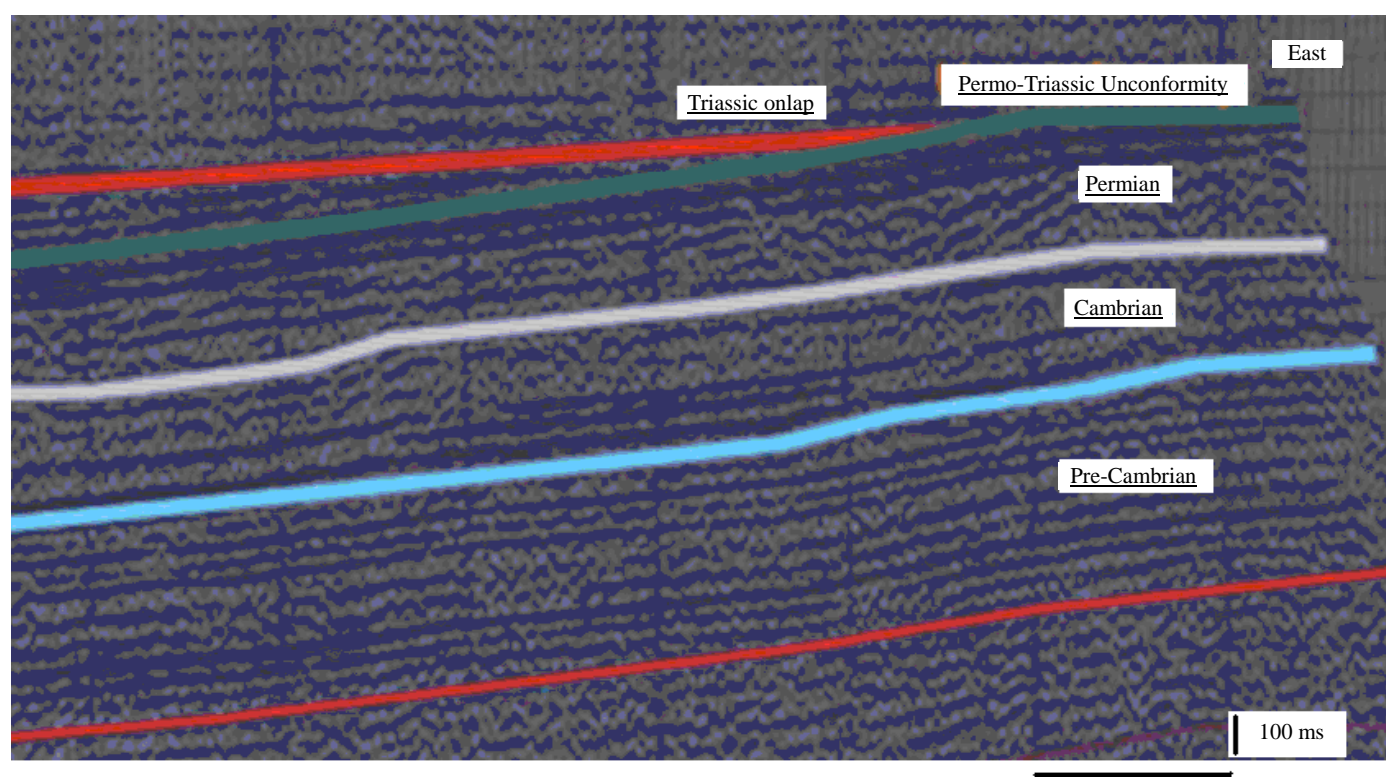

$1500 \mathrm{~m}$

Figure 9. Permo-triassic unconformity in east towards punjab platform (zoomed image of seismic profile).

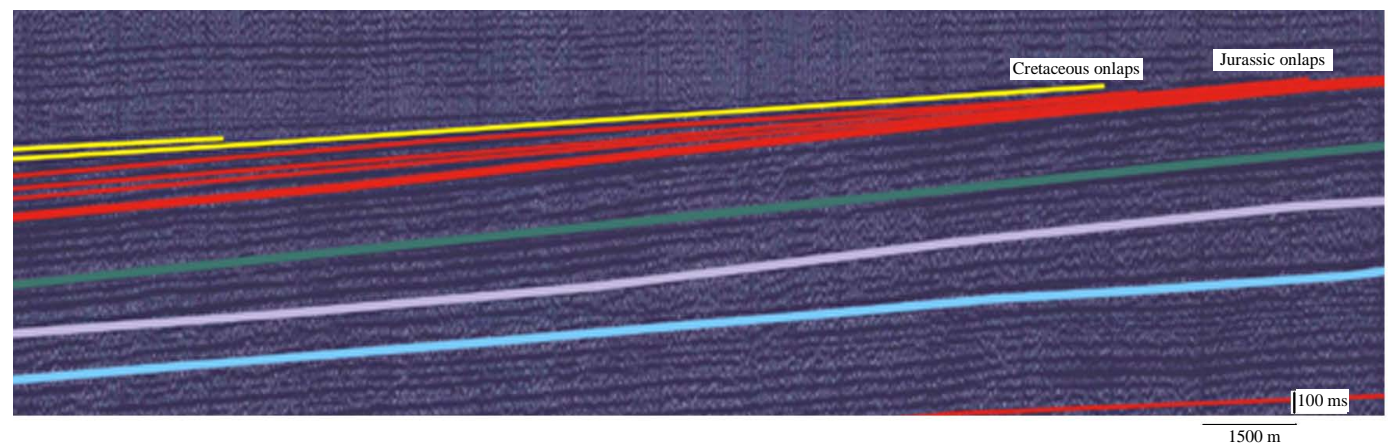

Figure 10. Jurassic \& cretaceous onlaps in east towards punjab monocline, indicating an area of non-deposition and suggesting sargodha high as an older feature than deposition of mesozoic sediments (zoomed image of seismic section).

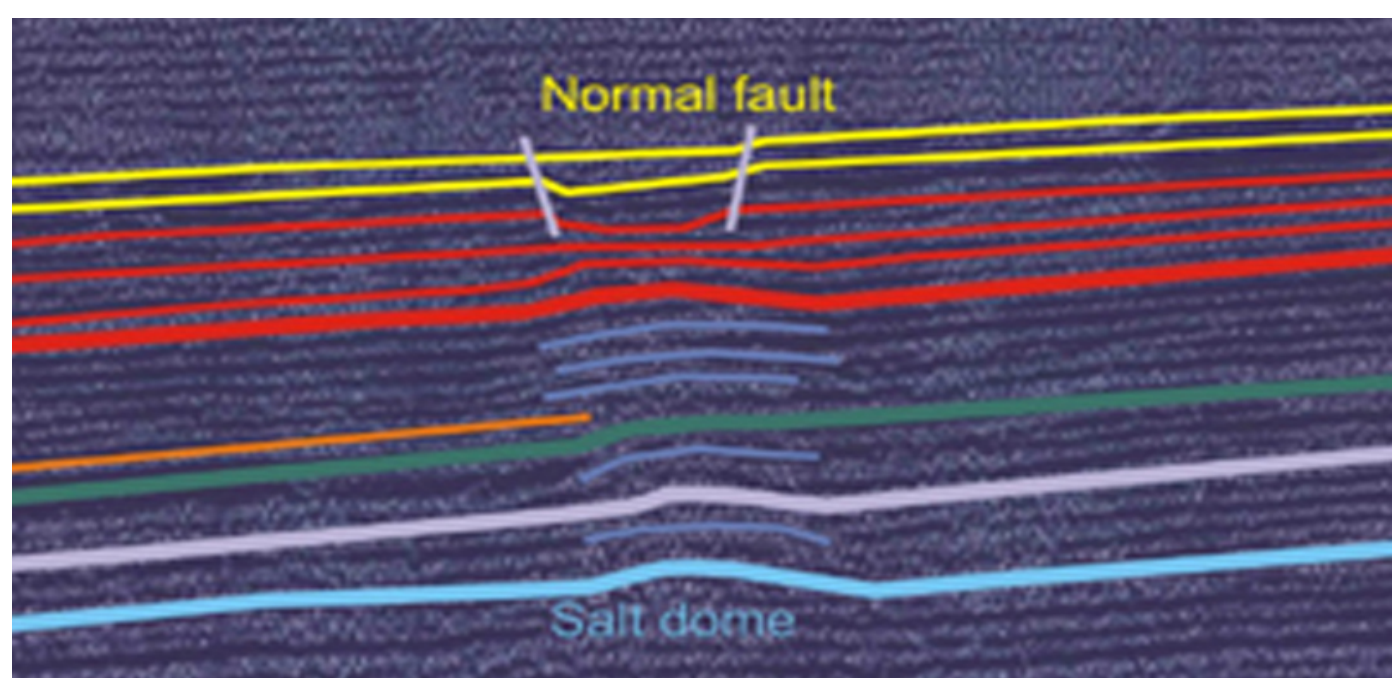

Figure 11. Salt dome and an associated graben structure on seismic profile. 


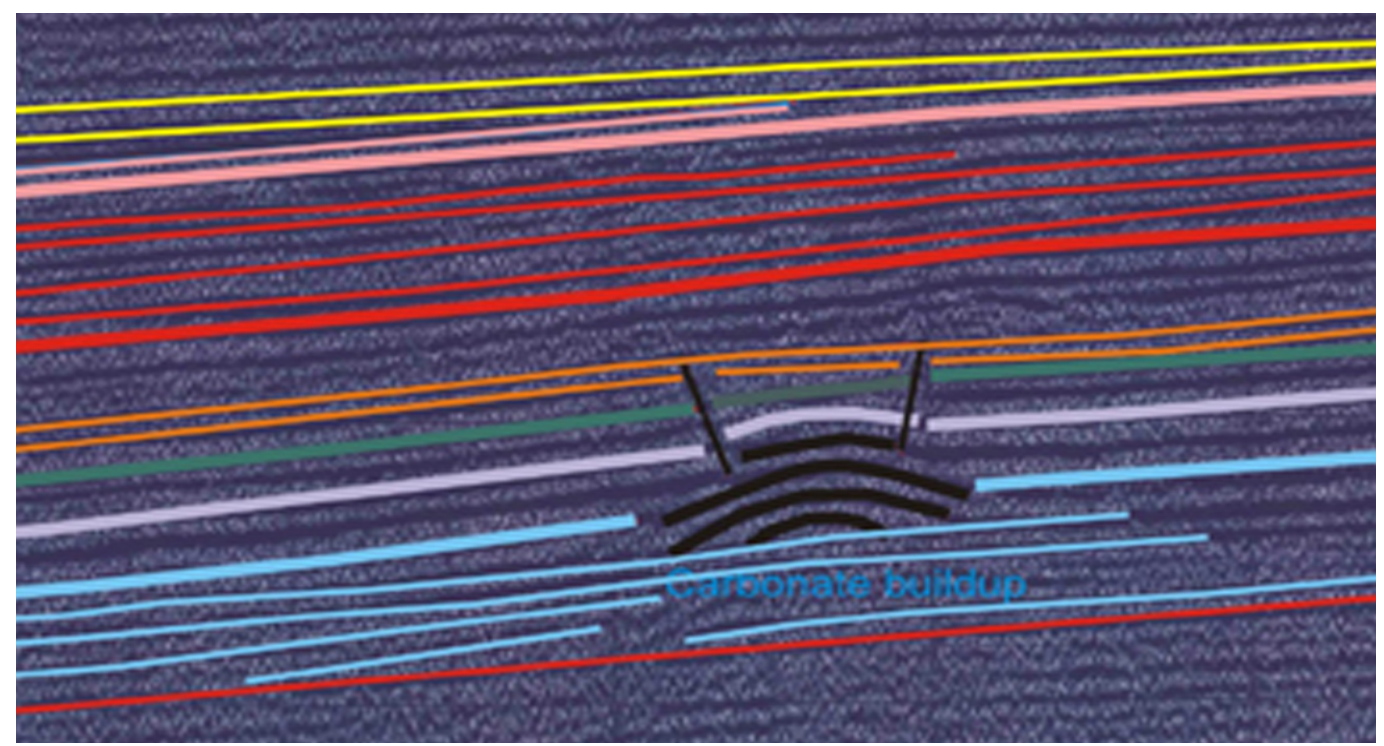

Figure 12. A buildup on seismic profile.

\section{Discussion, Conclusions \& Recommendations}

Deposition of Pre-Cambrian strata is uniform throughout the area. In east of the seismic profile thick Cambrian \& Permian strata is deposited. The basin depocenter lies in east at that time. Onlaps show the Cretaceous, Jurassic \& Triassic are not deposited in east towards Sargodha high, which suggests uplift in Paleozoic times. This shifted the depocenter of Mesozoic sediments westward. The Cretaceous, Jurassic and Triassic sediment are thick in west of seismic line. Paleozoic sediments are thinning in west.

Pre-Cambrian and Paleozoic sediments show a good hydrocarbon potentials for heavy oil in the eastern part of area. A Salt dome and a Buildup (carbonate/clastic) structure are potential features for hydrocarbon accumulation (heavy oil).

\section{Acknowledgements}

We are thankful to DGPC and LMKR for providing the data.

\section{References}

[1] Yeats, R.S. and Lawrence, R.D. (1984) Tectonics of the Himalayan Thrust Belt in Northern Pakistan, Marine Geology and Oceanography of Arabian Sea and Coastal Pakistan. In: Haq, B.U. and Milliman, J.D., Eds., Van Nostrand Reinhold Co., 177-198.

[2] Seeber, L. and Armbruster, J. (1979) Seismicity of the Hazara Arc in Northern Pakistan. Decollement versus Basement Faulting, Geodynamics of Pakistan, Geological Survey of Pakistan, Quetta, 131-147.

[3] Dolan, P., Edgar. D.C., Brand, C. and Shevlin, B.J. (1987) Pakistan, Regional Geology and Petroleum Exploration Potential. Dolan and Associates, Non-Exclusive Report, London.

[4] Menke, W. and Jacob, K.H. (1976) Seismicity Patterns in Pakistan and Northwestern India Associated with Continental Collision. Bulletin of the Seismological Society of America, 66, 1695-1711.

[5] Talent, J.A. and Mawson (1982) Intricacy of Tectonics in Chitral Hindukush: Faunal Evidence and Some Regional Implications. Himalayan Geology, Geological Survey India, Miscellaneous Publication, 77-101.

[6] Kadri, I.B. (1995) Petroleum Geology of Pakistan. Pakistan Petroleum Limited, 275 p.

[7] Raza, H.A., Ahmed, R., Ali, S.M. and Ahmad, J. (1989) Petroleum Prospects Sulaiman Sub Basin, Pakistan. Pakistan Journal of Hydrocarbon Research, 1, 21-56.

[8] Kemal, A., Balkwill, H.R. and Stoakes, F.A. (1991) Indus Basin Hydrocarbons Plays. International Petroleum Seminar on New Directions and Strategies for Accelerating Petroleum Exploration and Production in Pakistan, 16-57.

[9] Bender, F.K. and Raza, H.A. (1995) Geology of Pakistan. Borntraeger, Berlin, 145 p.

[10] Twiss, R.J. and Moores, E.M. (1992) Structural Geology. W.H. Freeman \& Company, 532 p. 
Scientific Research Publishing (SCIRP) is one of the largest Open Access journal publishers. It is currently publishing more than 200 open access, online, peer-reviewed journals covering a wide range of academic disciplines. SCIRP serves the worldwide academic communities and contributes to the progress and application of science with its publication.

Other selected journals from SCIRP are listed as below. Submit your manuscript to us via either submit@scirp.org or Online Submission Portal.
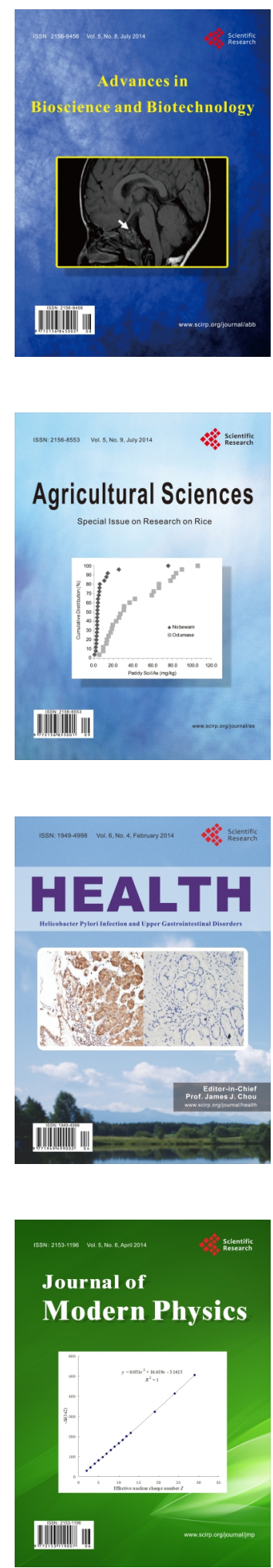
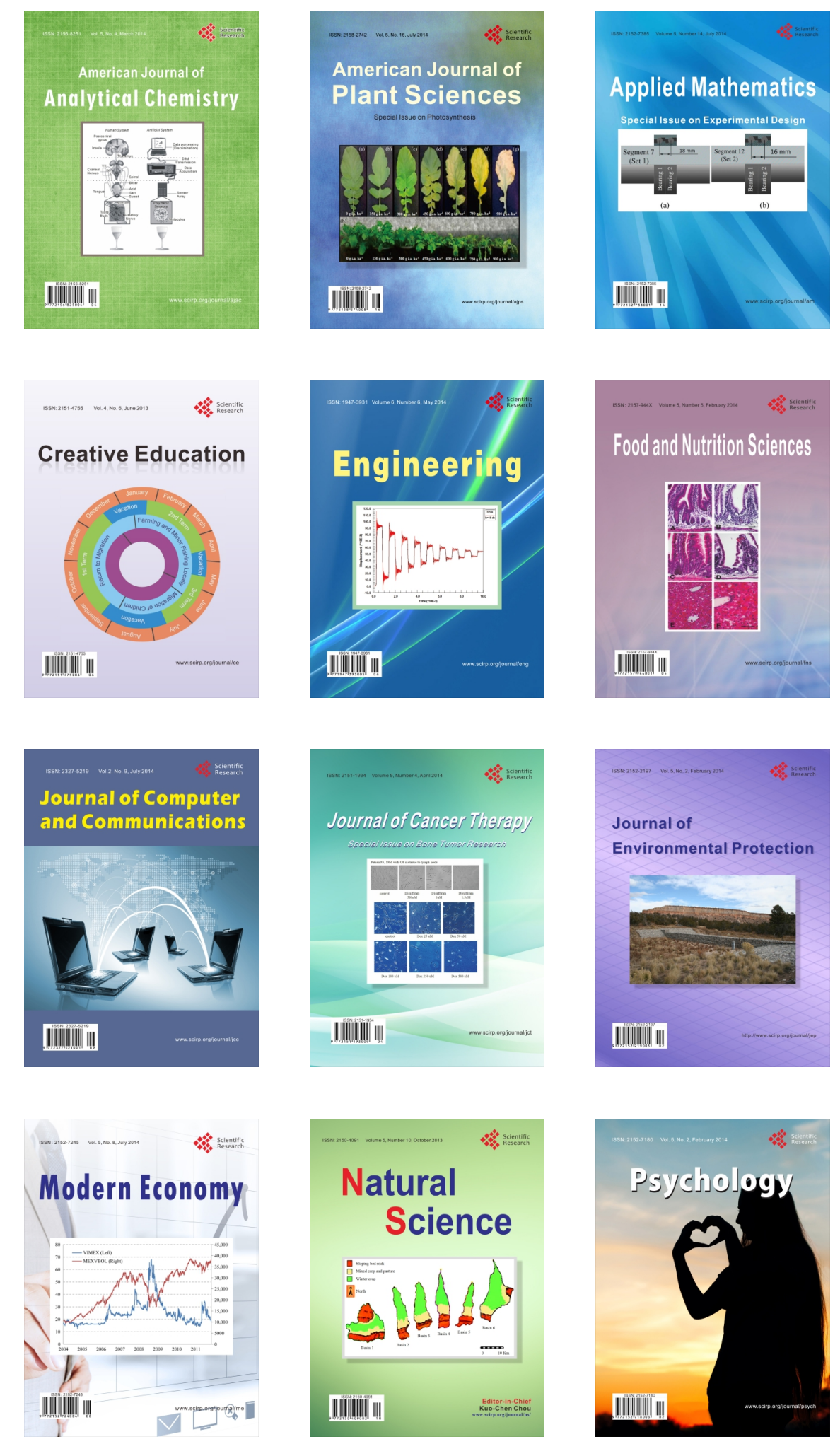